\title{
Assessment of Crime Incidence and Mitigation Strategies in Selected Indigenous Markets in Ibadan
}

\author{
ADIGUN Folasade Oyenike ABOLADE Olajoke* IGE James Olateju Oyelude Jumoke Abimbola \\ OLADELE Joshua Abayomi \\ Department of Urban and Regional Planning, \\ Ladoke Akintola University of Technology, Ogbomoso, Oyo State, Nigeria \\ *Corresponding Author
}

\begin{abstract}
The study examined the perceived incidence, causes and effects of crime within and around two selected indigenous markets in Ibadan. The primary data used in the study were sourced from traders, buyers and neighbouring residents through the use of questionnaire survey. Systematic and accidental samplings were used to select a total of 224 respondents. Four indices were developed: 'Incidence of Crime Index' (ICI), 'Causes of Crime Index' (CCI), 'Effects of Crime Index' (ECI) and 'Security Measures Index' (SMI). ICI, CCI, ECI and SMI were used to measure the incidence, causes and effects of crime as well as the security measures employed against crime in the selected markets and their neighbourhoods. The study observed that theft/ pick pocketing (4.54) and receiving stolen goods (4.47) were among the most prominent crime incidences. Poverty $(\mathrm{CCI}=4.34)$ and lack of education $(\mathrm{CCI}=4.34)$ are the highly perceived causes of crime in the study area. Loss of properties $(E C I=4.55)$ ranked highest in the respondents' perceived effect(s) of crime in the study area while loss of lives, fear of being the next victim and mental disorder also ranked high with ECI values $=4.13,4.12$ and 4.01 respectively. Special windows and doors lock had the highest usage index $(\mathrm{SMI}=3.91)$ while burglary proofing materials, security guards, vigilante, police, access road/ transport means and traditional means i.e. juju were similarly rated high with SMI values of 3.86, 3.85, 3.73, 3.51, 3.07 and 3.03 respectively. The study concluded that crime incidence in the area was serious and the residents were skeptical about police protection. However, it is suggested that relevant security agencies in the areas should adopt a proactive approach to crime prevention. This is premised on the fact that necessary and effective mechanisms for crime prevention are means of issuing strong deterrent signals to crime perpetrators and gives safety assurance to members of the society.
\end{abstract}

Keywords: Crime, Indigenous market, Mitigation, Strategies

DOI: $10.7176 / J L P G / 89-19$

Publication date:September $30^{\text {th }} 2019$

\section{Introduction}

In many urban centers of Nigeria, criminal activities and violence are assuming dangerous tendencies. It threatens lives, properties, national sense of well-being, peace, social order and security and consequently reduces citizens' life. (Agbola, 2000; Ahmed 2010). Noteworthy to say that Nigerian crime-problem is multidimensional. It is one of the social problems of urban development and the most notable threat to stable life style that is capable of undermining corporate existence as well as efforts towards sustainable economic development. Everywhere one goes in Nigeria especially the centre of the city, one is reminded of insecurity by troops of security personnel patrolling the streets. The concentration of violent crimes in major urban centers worldwide is therefore heralded as an indicator of the breakdown of urban systems (Oyebanji, 1982). The growth in urban crime rate in Nigeria is one of the major social problems facing the country in recent time (Agbola, 1997). The dominance of crime in developing countries increases the volatility of the issue, for it pyramids one fear upon others (Onoge, 1998). Nothing has become more incurable in urban centres of Nigeria than incessant occurrence of crime. These often constitute nuisance to Nigerian causing sleeplessness at night as a result of fear of being the next victim of armed robbers, paid assassins, political thugs and other criminals who treat human lives. Further to this, is the fact that Nigerian police collide with the men of the underworld to unleash terror on their fellow countrymen (Agbola, 1997).

Schaefer (1989) referred to crime as a violation of criminal law which its formal penalties are applied by some governmental authority. Crime according to (Dambazu, 1994) is something which offends the morality of society, or that violates the divine law. The consensus approach to defining crime presents it as; an offence that is committed by omission, commission or deliberately. Crime is a universal phenomenon that differs only in degree among the various nations of the world (Okafor, 2011) and from one place to the other even within a nation. Not only this, the incidence of crime also cut across various epoch of human existence and is as old as human society. Suffice to say that crime is a social malady with spatial and temporal dimensions.

Various studies have been undertaken on the spread of crime spatially (Abodunrin, 2005; Aguda, 1994; Agbola, 1997; Afon, 2001; Agbola, 2002; Adedibu and Abodunrin, 2005, Ahmed 2012) and temporally (Omisakin, 1998; Agbola and Sobanjo, 2002; Abodunrin, 2004; Adeboyejo and Abodunrin, 2004; Adigun and Adedibu 2013). Argument on the spatial spread of crime is premised on the use and the arrangement of the 
physical elements of the environment to deter crime incidences These explains variations in incidences, causes and impacts of crime from one land use to the other. The variations explains the trend of crime and associated factors and sometimes provide a forecast of future trend.

Markets as one of the major land uses in any human setting is susceptible to criminal activities. Markets are very vital in the economic life of the people and are essential in the chain of commodity distribution (Balogun, 1998). 'Market is defined as an area or setting regardless of its distance, time and size within which producers and consumers are in communication with each other for exchange of goods and commodities. According to Vagale (1973) markets are not only economic institutions but also serve as social entities in the sense that they forge links between people of diverse ethnic groups, racial backgrounds and cultural trait, and also serve as meeting places for socio-cultural, religious and political activities. In the literal observation and for the purpose of this study markets provide a physical setting for interaction between different cultures. The interest of this study centres on the physical settings called markets especially the indigenous ones whose existence has been deeply woven into the fabric of the society where they exists.

The Nigeria corporate existence and development can be weakened by a number of factors among which is an escalating and uncontrolled crime problem (Taminu, 2006). Security and crime have been deeply rooted in the political history of this country, particularly in recent time, which has emerged as a key concept in Nigeria's struggle for good governance, sustainable democracy and development. Previous efforts made by government at controlling crime in Nigeria took the use of police, courts, correction officers and others who work in the criminal justice system and in related institution like the mental health and juvenile justice system (Dambazu 1994, Alemika 1997, Okunola 2002, Hale, 2004, Kornblum and Julian 2004). There were also individual and community efforts such installation of burglary proof, use alarm system, strong locks and other security barriers. At the community level, road bumps and gates are made, security guards are employed while male residents sometimes do routine patrol of their community. Despite these efforts crime do not only increase but it's becoming a permanent feature of the society.

More so, it is greatly observed that in an attempt to establish a secure neighbourhood for sustainable cities, friendly region and better environment that can make people enjoy a stable life style. The habit of studying crime mostly in major urban centres, towns and urban local government areas dominate the limited crime research efforts come across in Nigeria (Ige, 2015). These studies include the ones reviewed in this work and others such as (Adelakun, 1990; Egwu, 1990; Odekunle, 2005; Akinrinde, 2007; Arinze, 2010; Ajibade, Olopade and Erinosho, 2011) to identify the factors responsible for the rising crime incidence in Nigeria in general and Ibadan in particular. For instance, Adelakun and Egwu, 1990 traced the problem to the crisis of global capitalism with its cycles of booms and recession (Okafor, 2011).

There are little or no attempts to study indigenous market crime from the spatio-criminological point of view. Despite the age long crime research and long history of present crime control measures, the crime occurrence continues to worsen both quantitatively and qualitatively that urban environment with an overall conception of and policy on crime and its control have no less serious crime effects than the past. The situation is so bad that crime and violence do not only continue to exist, but become more and more acute such that they daily increase in intensity and magnitude, severity and impact. The problem lies in excessive concentration to capture varied and various roots of issues that exist on market crime that are predominantly non-indigenous.

This research therefore seeks to analyze incidence of crime in selected indigenous markets and the strategies of crime prevention and control in Ibadan with a view to proffer measures of combating this social menace. The specific objectives put forward to examine the incidence and types of crime in the selected traditional markets in the city of Ibadan, investigate the causes and effects of crime in the area, and assess the responses of traders and buyers to criminal victimization in the study area.

Ibadan one of the fastest growing cities in Nigeria is located in Oyo State in the South-west geo-political zone of Nigeria. The State is bounded on the North by Kwara State, on the South by Ogun State, on the West by the state of Osun and on the West by the neighboring Republic of Benin. The city of Ibadan is located approximately on longitude $3^{0} 5^{1}$ East of the Greenwich Meridian and latitude $7^{0} 23^{1}$ North of the Equator, and its 145 kilometers away from Lagos. Ibadan is directly connected to many towns in Nigeria, as its rural hinterland by a system of roads, railways and air routes. The physical setting of the city consists of ridges of hills that run approximately in northwest-southeast direction. The largest of these ridges lies in the central part of the city and contains such as peaks as Mapo, Mokola and Aremo. These hills range in elevation from 160 to 275 meters above sea level and thus afford the visitor a panoramic view of the city

\section{Research Methodology}

The study employed both primary and secondary sources of information. The primary data were sourced through the use of questionnaire survey and key informant interview method. In- depth interviews were conducted on key actors in the markets, local Government areas (Ibadan North East Local Government and Ibadan South East Local Government), ministries and parastatals. The primary data used include socio-economic status of the 
traders, incidence of criminal victimization, traders' perception of the causes and effects of crime, security strategies adopted by the traders against crime in the study area among others. Frontiers of information about the subject were obtained from related research reports and or articles both published and unpublished. Crime figures and the spread of police units across the study area were obtained from The Nigerian Police Force Headquarters at Agugu and concerned Divisional Police Offices within the study area.

Urban Ibadan is made up of five Local Government Areas. For the purpose of this study, two local government areas where traditional markets are highly predominant were purposively selected for the study. These are Ibadan North East and Ibadan South East. Fourteen traditional markets were identified in the two selected LGAs, five and nine markets in Ibadan North East and Ibadan South East LGA respectively. Out of these a traditional market that was centrally located was randomly selected from each .LGAs. Oje in Ibadan North East was selected, while Oja'ba was selected from Ibadan South East. (Table 1)

Table 1: Markets in each of the Selected LGA in Ibadan

\begin{tabular}{|l|l|l|}
\hline S/N & Local Government Areas & Markets \\
\hline 1 & Ibadan North East & $\begin{array}{l}\text { Academy, Agugu, Orita-Aperin, Ode-aje-alalubosa } \\
\text { and Oje. }\end{array}$ \\
\hline 2 & Ibadan South East & $\begin{array}{l}\text { Agbeni, Alafara-olubadan, Ayeye, Beere, Challenge, } \\
\text { Ifeleye, Ogunpa, Oja'ba and Orita merin. }\end{array}$ \\
\hline
\end{tabular}

Source: Author's Field Survey, 2015.

Random and accidental samplings were used to sample traders and buyers respectively in the selected markets. Accidental sampling was used to sample the buyers because they are mobile not stationed at a particular place unlike the traders. Systematic sampling was employed in selecting traders for the questionnaire administration. This involves choosing the $3^{\text {rd }}$ trader on each street in the selected markets and then choosing subsequent traders at an interval of five such that not more than six traders was selected in each street until the required number of traders were obtained for each market. The choice of the selected traders was based on the availability of the traders at the time of visits. A total number of 167 traders were sampled comprising 78 in Oja'ba and 89 in Oje markets. A total of 30 buyers were sampled such that 12 at Oja'ba and 18 at Oje markets. The selected markets were located on Goggle Earth Imagery of the area. A radius of 150 meters was carved around each markets. These comprise of 305 and 280 buildings around Oje and Oja' ba market respectively. A total of 30 and 27 buildings were sampled around Oje and Oja' ba market respectively. From each sampled buildings a respondent was surveyed. Thus the total number of sampled respondents is 57 . Descriptive statistics such as frequencies and percentages were used to summarize findings. Four indices were developed: 'Incidence of Crime Index' (ICI), 'Causes of Crime Index' (CCI), 'Effects of Crime Index' (ECI) and 'Security Measures Index' (SMI).ICI, CCI, ECI and SMI were used to measure the incidence, causes and effects of crime as well as the security measures employed against crime in the selected markets and their neighbourhoods.

\section{RESULTS AND DISCUSSION}

3.1 Respondents' Perception of Incidence of Crime

Table 2: Perception of Incidence of Crime in the Market

\begin{tabular}{|c|c|c|c|c|c|c|c|c|c|c|c|}
\hline 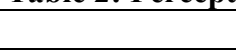 & \multicolumn{5}{|c|}{ Ranking } & \multicolumn{6}{|c|}{ Incidence of Crime Index } \\
\hline Types of crime & 5 & 4 & 3 & 2 & 1 & $\sum_{(\mathbf{f})}$ & $\sum \mathbf{f}(\mathbf{x})$ & ICI & $\mathbf{X}$ & $\mathbf{D}$ & $d^{2}$ \\
\hline $\begin{array}{ll}\text { Theft/ } \\
\text { pocketing }\end{array}$ & 635 & 352 & 21 & 2 & 0 & 224 & 1016 & 4.54 & \multirow{11}{*}{3.204} & 1.336 & 1.79 \\
\hline $\begin{array}{l}\text { Receiving stolen } \\
\text { goods }\end{array}$ & 645 & 320 & 27 & 8 & 2 & 224 & 1002 & 4.47 & & 1.266 & 1.60 \\
\hline $\begin{array}{l}\text { Destruction of } \\
\text { property }\end{array}$ & 615 & 340 & 33 & 6 & 2 & 224 & 996 & 4.45 & & 1.246 & 1.55 \\
\hline Drug abuse & 555 & 252 & 27 & 50 & 16 & 224 & 900 & 4.02 & & 0.816 & 0.67 \\
\hline Assault & 525 & 267 & 45 & 18 & 6 & 224 & 861 & 3.84 & & 0.636 & 0.41 \\
\hline Rape & 55 & 60 & 147 & 208 & 45 & 224 & 515 & 2.30 & & -0.904 & 0.82 \\
\hline Armed robbery & 95 & 80 & 102 & 168 & 67 & 224 & 512 & 2.29 & & -0.914 & 0.84 \\
\hline Abduction & 20 & 96 & 123 & 144 & 83 & 224 & 466 & 2.08 & & -1.124 & 1.26 \\
\hline $\begin{array}{l}\text { Forgery and } \\
\text { currency crime }\end{array}$ & 45 & 24 & 78 & 260 & 53 & 224 & 460 & 2.05 & & -1.154 & 1.33 \\
\hline Car snatching & 40 & 28 & 90 & 220 & 69 & 224 & 447 & 2.00 & & -1.204 & 1.45 \\
\hline Total & & & & & & & & 32.04 & & & 11.72 \\
\hline
\end{tabular}

Source: Author's Field Survey, 2015

It was observed that theft/ pick pocketing had the highest index value of $I C I=4.54$. This implies that theft/ 
pick pocketing was very frequent in the study area. The next crime was 'receiving stolen goods' $($ ICI $=4.47)$, destruction of property, drug abuse, assault with significance ICI index value of 4.45, 4.02 and 3.84 respectively. However, rape, armed robbery, abduction, forgery and currency crime and car snatching had the lowest index values of 2.30, 2.29, 2.08, 2.05 and 2.00 respectively. Meanwhile, it does not necessarily mean that crime type with negative deviation from the mean frequency of crime index were totally 'non-occurring'. The fact remains that in the cumulative ranking, they occurred less.

3.2 Types of Crime Respondents has been a Victim of Crime in the study Area Table 3: Types of crime respondents has been a victim of in the study

\begin{tabular}{|l|c|c|}
\hline & Frequency & Percentage (\%) \\
\hline Abduction & 5 & 2.2 \\
\hline Armed robbery & 14 & 6.3 \\
\hline Assault & 68 & 30.4 \\
\hline Car snatching & 1 & 0.4 \\
\hline Destruction of property & 37 & 16.5 \\
\hline Drug abuse & 2 & 0.9 \\
\hline Forgery and currency crime & 4 & 1.8 \\
\hline Rape & 1 & 0.4 \\
\hline Receiving stolen goods & 34 & 15.2 \\
\hline Theft/ pick pocketing & 58 & 25.8 \\
\hline Total & $\mathbf{2 2 4}$ & $\mathbf{1 0 0 . 0}$ \\
\hline
\end{tabular}

\section{Source: Author's Field Survey, 2015}

It was observed that assault had the highest proportion of $30.4 \%$. Next was theft/ pick pocketing $(25.8 \%)$, destruction of property $(16.5 \%)$ and receiving stolen goods $(15.2 \%)$. The difference in this result compared with the data presented on Table 5 should not be interpreted as contradictory. It should be noted that the experienced of people coupled with the news of crime cumulated into their perception of crime incidence in the area. As individuals, majority had experienced assaults while cumulatively incidence of theft/ pick pocketing perceived to be more (see Table 4 and 5). Meanwhile, crime types with the least proportion include; car snatching and rape $(0.4 \%$ each), armed robbery $(6.3 \%)$, abduction $(2.2 \%)$, forgery and currency crime $(1.8 \%)$, drug abuse $(0.9 \%)$.

This survey showed that assault was the most experienced crime in the study area. Respondents refuse to report to the police because of fear of reprisal attack and slow pace of proceedings. Theft/ pick pocketing and destruction of property were also experienced considerably in the area.

3.3 Perceived Perpetrators of Crime in the Area Table 4: Perceived Perpetrators of Crime

\begin{tabular}{|c|c|c|}
\hline & Frequency & Percentage (\%) \\
\hline Less than 18 years & 6 & 2.7 \\
\hline 19-39 years & 189 & 84.4 \\
\hline 40-59 years & 29 & 12.9 \\
\hline Above 60 years & 0 & 0 \\
\hline Total & $\mathbf{2 2 4}$ & $\mathbf{1 0 0 . 0}$ \\
\hline
\end{tabular}

Source: Author's Field Survey, 2015

An overwhelming proportion of $84.4 \%$ of the total respondents were of the view that members of the society between the ages 19-39 years were the largest perpetrators of crime. Respondents who suggested that persons between the ages $40-59$ years were the major game players of crime are $12.9 \%$ while $2.7 \%$ suggested that persons below the age of 18 years were the ones committing crime most. The trend presented above was unsurprising because respondents within the age bracket of 19-39 years dominate the study area. The analysis above could be said to portend a dangerous direction to the magnitude of crime experienced. This happens to be the age bracket of agile and vibrant members of the society and those within this age bracket could be lured to indulge in crime in order to make ends meet. This might therefore necessitate a stringent and dynamic response to crime because of the dynamism associated with youthful thinking and tactics. This standpoint does not exonerate other age groups from crime as there are big old men who happen to be bank rolling young criminals (Adigun, 2012). 
3.4 Respondents' perceived cause of crime in the study area

Table 5: Respondents' perceived cause of crime in the study area

\begin{tabular}{|c|c|c|c|c|c|c|c|c|c|c|c|}
\hline & \multicolumn{5}{|c|}{ Ranking } & \multicolumn{6}{|c|}{ Causes of Crime Index } \\
\hline Causes of crime & 5 & 4 & 3 & 2 & 1 & $\begin{array}{l}\sum \mathbf{f} \\
\text { (f) }\end{array}$ & $\sum \mathbf{f}(\mathbf{x})$ & CCI & $\mathbf{X}$ & $\mathbf{d}$ & $d^{2}$ \\
\hline Unemployment & 530 & 404 & 6 & 8 & 10 & 224 & 958 & 4.28 & \multirow{10}{*}{3.94} & 0.34 & 0.12 \\
\hline Poverty & 500 & 436 & 15 & 20 & 0 & 224 & 971 & 4.34 & & 0.4 & 0.16 \\
\hline Lack of education & 605 & 312 & 30 & 18 & 6 & 224 & 971 & 4.34 & & 0.4 & 0.16 \\
\hline Indecent dressing & 135 & 320 & 174 & 108 & 5 & 224 & 742 & 3.31 & & -0.63 & 0.40 \\
\hline Depression & 180 & 340 & 132 & 88 & 15 & 224 & 755 & 3.37 & & -0.57 & 0.33 \\
\hline Low self esteem & 180 & 320 & 150 & 80 & 18 & 224 & 748 & 3.34 & & -0.6 & 0.36 \\
\hline Parental neglect & 520 & 380 & 42 & 12 & 5 & 224 & 959 & 4.28 & & 0.34 & 0.12 \\
\hline Overpopulation & 530 & 368 & 30 & 20 & 6 & 224 & 954 & 4.26 & & 0.32 & 0.10 \\
\hline Drug abuse & 395 & 388 & 24 & 68 & 6 & 224 & 881 & 3.93 & & -0.01 & 0.0001 \\
\hline Total & & & & & & & & 35.45 & & & 1.7501 \\
\hline
\end{tabular}

\section{Source: Author's Field Survey, 2015}

The mean value of the causes of crime index $(\mathrm{CCI})$ is 3.94 . Poverty $(\mathrm{CCI}=4.34)$ and lack of education $(\mathrm{CCI}=4.34)$ had the highest occurrence index value among the various perceived causes of crime in the study area. Unemployment $(\mathrm{CCI}=4.28)$, parental neglect $(\mathrm{CCI}=4.28)$ and overpopulation $(\mathrm{CCI}=4.26)$ also ranked high in the respondents' perceived causes of crime in the study area. The indicated causes of crime suggest that efforts by the government should be geared towards improving the standard of living of respondents. The need to provide the police with necessary equipment aimed at combating crime cannot be overemphasized.

\subsection{Period in which miscreants perform their vices}

Table 6: Period in which miscreants perform their vices

\begin{tabular}{|l|c|c|}
\hline Time & Frequency & Percentage (\%) \\
\hline Mornings (12am-11am) & 59 & 26.3 \\
\hline Afternoons (12pm-4pm) & 29 & 12.9 \\
\hline Evenings (5pm-7pm) & 45 & 20.1 \\
\hline Nights (8pm-11pm) & 91 & 40.6 \\
\hline Total & $\mathbf{2 2 4}$ & $\mathbf{1 0 0 . 0}$ \\
\hline
\end{tabular}

Source: Author's Field Survey, 2015

A considerable proportion $(40.6 \%)$ of the respondents noted that miscreants performed their vices between $8 \mathrm{pm}-11 \mathrm{pm}$ while $26.3 \%$ of the respondents indicated that miscreants raid the area in the morning between the hours of $12 \mathrm{am}-11 \mathrm{am}$. Some respondents $(20.1 \%)$ indicated that period of crime victimization in the area was in the evening between $5 \mathrm{pm}-7 \mathrm{pm}$ and $12.9 \%$ believed that vices were done in the afternoon.

3.6 Principal victims of the identified criminal activities

Table 7: Principal victims of the identified criminal activities

\begin{tabular}{|l|c|c|}
\hline & Frequency & Percentage (\%) \\
\hline Buyers & 68 & 30.4 \\
\hline Traders & 105 & 46.9 \\
\hline Residents & 51 & 22.8 \\
\hline Total & $\mathbf{2 2 4}$ & $\mathbf{1 0 0 . 0}$ \\
\hline
\end{tabular}

Source: Author's Field Survey, 2015

The data on Table reveals the principal victims of criminal activities in the study area are traders. The next group is the buyer (30.4\%) and residents living near the market $(22.8 \%)$. 
3.7 Respondents' Perception on the Effects of Crime

Table 8: Respondents' perception on the effects of crime

\begin{tabular}{|c|c|c|c|c|c|c|c|c|c|c|c|}
\hline & & RaI & ing & & & & Effects & of Crim & ndex & & \\
\hline Effects of crime & 5 & 4 & 3 & 2 & 1 & $\begin{array}{l}\sum_{\mathbf{f}} \mathbf{f} \\
\text { (f) }\end{array}$ & $\sum \mathbf{f}(\mathbf{x})$ & ECI & $\mathbf{X}$ & d & $d^{2}$ \\
\hline $\begin{array}{l}\text { Ineffectiveness of } \\
\text { police }\end{array}$ & 750 & 236 & 36 & 9 & 0 & 224 & 1031 & 4.60 & \multirow{9}{*}{4.00} & 0.6 & 0.36 \\
\hline Loss of property & 675 & 308 & 34 & 2 & 0 & 224 & 1018 & 4.55 & & 0.55 & 0.302 \\
\hline Loss of lives & 460 & 360 & 69 & 36 & 1 & 224 & 926 & 4.13 & & 0.13 & 0.017 \\
\hline $\begin{array}{l}\text { Fear of being the } \\
\text { next victim }\end{array}$ & 435 & 368 & 93 & 24 & 2 & 224 & 922 & 4.12 & & 0.12 & 0.014 \\
\hline Mental disorder & 310 & 480 & 72 & 34 & 1 & 224 & 897 & 4.01 & & 0.01 & 0.0001 \\
\hline Disabilities & 315 & 480 & 57 & 36 & 4 & 224 & 892 & 3.98 & & -0.02 & 0.0004 \\
\hline Suicide & 240 & 320 & 96 & 110 & 9 & 224 & 775 & 3.46 & & -0.54 & 0.292 \\
\hline $\begin{array}{lr}\text { Design } & \text { of } \\
\text { building } & \text { within } \\
\text { the area } & \\
\end{array}$ & 135 & 296 & 123 & 150 & 7 & 224 & 711 & 3.17 & & -0.83 & 0.689 \\
\hline Total & & & & & & & & 32.02 & & & 1.675 \\
\hline
\end{tabular}

Source: Author's Field Survey, 2015

The mean value of the effect of crime index $(\mathrm{ECI})$ was 4.0. Ineffectiveness of the police $(\mathrm{ECI}=4.60) \mathrm{had}$ the highest occurrence index value among the various perceived effects of crime in the study area. Loss of property $(\mathrm{ECI}=4.55)$ also ranked high in the respondents' perceived effect(s) of crime in the study area while loss of lives, fear of being the next victim and mental disorder also ranks high with 4.13, 4.12 and 4.01 respectively. However, disabilities, suicide and design of building within the area have the low ECI value of $3.98,3.46$ and 3.17 respectively with negative deviations from the mean. Meanwhile, it does not necessarily indicate that variables with negative deviation from the mean were not experienced but their impacts were lesser than others.

\subsection{Response to Criminal Activities in the Area}

Table 9: Security measures in the market/ community

\begin{tabular}{|c|c|c|c|c|c|c|c|c|c|c|c|}
\hline & \multicolumn{5}{|c|}{ Ranking } & \multicolumn{6}{|c|}{ Security Measures Index } \\
\hline Security measures & 5 & 4 & 3 & 2 & 1 & $\begin{array}{l}\sum \mathbf{f} \\
(\mathbf{f})\end{array}$ & $\sum \mathbf{f}(\mathbf{x})$ & SMI & $\mathbf{X}$ & $\mathbf{D}$ & $d^{2}$ \\
\hline $\begin{array}{l}\text { Special windows and door } \\
\text { locks }\end{array}$ & 550 & 244 & 21 & 30 & 31 & 224 & 876 & 3.91 & \multirow{14}{*}{2.90} & 1.01 & 1.02 \\
\hline Burglary proofing materials & 455 & 312 & 15 & 64 & 32 & 224 & 864 & 3.86 & & 0.96 & 0.92 \\
\hline Security guards & 280 & 412 & 99 & 58 & 13 & 224 & 862 & 3.85 & & 0.95 & 0.90 \\
\hline Vigilante & 150 & 432 & 249 & 4 & 1 & 224 & 836 & 3.73 & & 0.83 & 0.69 \\
\hline Police & 110 & 304 & 360 & 10 & 1 & 224 & 785 & 3.51 & & 0.61 & 0.37 \\
\hline Access road/ transport means & 50 & 92 & 498 & 44 & 3 & 224 & 687 & 3.07 & & 0.17 & 0.03 \\
\hline Traditional means i.e. juju & 85 & 172 & 354 & 44 & 24 & 224 & 679 & 3.03 & & 0.13 & 0.02 \\
\hline Gun & 35 & 140 & 366 & 90 & 15 & 224 & 646 & 2.88 & & $-\overline{0}$ & 0.0004 \\
\hline Street lighting & 60 & 84 & 390 & 86 & 18 & 224 & 638 & 2.85 & & $\overline{-}-\overline{0}$ & 0.003 \\
\hline OPC & 130 & 92 & 99 & 196 & 44 & 224 & 561 & 2.51 & & $\begin{array}{l}- \\
0.39\end{array}$ & 0.15 \\
\hline Community gate & 180 & 40 & 18 & 80 & 132 & 224 & 450 & 2.01 & & $-\overline{0}$ & 0.79 \\
\hline Alarm system & 10 & 20 & 33 & 50 & 181 & 224 & 294 & 1.31 & & $-\overline{1.59}$ & 2.53 \\
\hline Closed circuit television & 0 & 8 & 6 & 56 & 192 & 224 & 262 & 1.17 & & $\begin{array}{ll} \\
1.73\end{array}$ & 2.99 \\
\hline Total & & & & & & & & 37.69 & & & $\mathbf{1 0 . 4 1 3 4}$ \\
\hline
\end{tabular}

Source: Author's Field Survey, 2015

The level of usage of different security measures was documented in table 4.15 . The mean for the security measure index (SMI) is 2.90. Special windows and doors lock had the highest usage index of $(\mathrm{SMI}=3.91)$ while 
burglary proofing materials, security guards, vigilante, police, access road/ transport means and traditional means i.e. juju also had the highest usage rank of 3.86, 3.85, 3.73, 3.51, 3.07 and 3.03 respectively. Meanwhile, gun, street lighting, OPC, community gate, alarm system and closed circuit television had the lowest level of usage index of 2.88, 2.85, 2.51, 2.01, 1.31 and 1.17 respectively with negative deviations from the mean. Meanwhile, it does not necessarily mean that variables with negative deviation from the mean frequency of crime index were totally 'non-occurring'. The fact remains that in the cumulative ranking, they occurred less.

The situation in the study area reveals that the usage of security measures decreases as one move away from the area. This might be associated from the fact that most of the respondents cannot afford all sorts of sophisticated security gadgets and they will want to make use of whatever security measures they can afford.

Table 10: Response to criminal activities in the area

\begin{tabular}{|l|c|c|}
\hline & Frequency & Percentage (\%) \\
\hline Calling on the community security men & 70 & 31.3 \\
\hline Calling on your neighbours for help & 122 & 54.5 \\
\hline Total & $\mathbf{1 9 2}$ & $\mathbf{8 5 . 7}$ \\
\hline
\end{tabular}

Source: Author's Field Survey, 2015

Respondents who called on neighbors in the event of a criminal attack accounted for 54.5\% while respondents who called on the community security men accounted for $31.3 \%$. This implies that respondents who preferred to call on their neighbor for help claimed the highest percentage because they believed their neighbors would come to their rescue before the community security men come to render assistance.

Table 11: Crime reporting by respondents to the police

\begin{tabular}{|l|c|c|}
\hline & Frequency & Percentage (\%) \\
\hline Yes & 55 & 25.0 \\
\hline No & 168 & 75.0 \\
\hline Total & $\mathbf{2 2 4}$ & $\mathbf{1 0 0 . 0}$ \\
\hline
\end{tabular}

Source: Author's Field Survey, 2015

Respondents that did not report crime incidence(s) to the police constituted the highest percentage of $75.0 \%$ while a minor proportion of $25 \%$ reported crime incidences to the police. This might had serious implications. Ineffectiveness of the police ranked highest amongst the reason(s) attributed to non-reporting of crime experienced to the police. Next was lack of trust in the police with $23.7 \%$, slow pace of proceedings with $16.1 \%$ and fear of reprisal of attack with $7.6 \%$. From this, it could be concluded that ineffectiveness of police in the study area is high. Respondents that did not report to the police would prefer to apply jungle justice on criminal because of the attitude of the police. The fear of being arrested could also deter the respondents of the study area from reporting crime cases as they could be victimized as perpetrators of the same crime they reported to the police. The corruption of police officers who request for monetary gains for reporting crime also deterred most respondents of the study area from reporting crime experienced to the police

Table 12: Respondents perceived reasons for not reporting crime to the police

\begin{tabular}{|l|c|c|}
\hline & Frequency & Percentage (\%) \\
\hline Lack of trust in police & 53 & 23.7 \\
\hline Fear of reprisal of attack & 17 & 7.6 \\
\hline Slow pace of proceedings & 36 & 16.1 \\
\hline Ineffectiveness of the police & 62 & 27.7 \\
\hline Total & $\mathbf{1 6 8}$ & $\mathbf{7 5 . 0}$ \\
\hline
\end{tabular}

Source: Author's Field Survey, 2015

\section{Policy Oriented Remarks and Conclusion}

From the previous findings and discussions, in order to permanently circumvent the incidence of crime or at least reduce it in the study area having identified factors which causes crime in the study area, the following suggestions are therefore put forward. It is expected that these improve the well-being of people in the study area if implemented.

Although, the study revealed that just $27.7 \%$ of the respondents believed that police were ineffective and there was still the need for the relevant security agencies in the areas to adopt a proactive approach to crime prevention. This was because when the necessary mechanisms for crime prevention were in place and adequately effective, it sent a message to the minds of the crime perpetrators and the respondents. With this, those intending to carry out criminal activities would have a rethink while members of the society at large would be assured of the safety of their lives and properties.

Police should be encouraged and be implored to be more engaged in community policing by good payment by the government and provision of sophisticated ammunitions which would enhance proper crime combating. The possibility of training vigilante groups to assist it in the work of surveillance should also be explored. There 
is need for retraining and refocusing the Police Force. Background checks should be made at recruitment to ensure that only persons of integrity and proper education are taken. Training should focus more on investigation and surveillance techniques, record keeping and handling crisis situations. To attain this, there is need to recruit persons who have proper educational qualifications. For a secured and safe society, the need for a synergy between the security agencies and respondents are very important. Hence, to achieve a collaborative effort at reducing crime, there is the need for a high level of trust between respondents and the police. Public policy should simplify crime reporting procedures to further encourage respondents to report crimes involving them.

In addition, the use of other safety measures apart from the Police should be applied based on the prevailing socio-economic of the study areas. For instance, it was observed that most of the respondents employ the use of special windows and doors lock in the areas in securing their properties while some employ the use of burglary proofing materials.

It is however worrisome that all these societal odds are interwoven and brunt of this fault can be put at the feet of the government. The need therefore for the government to create more employment opportunities, ensure the adequate strengthening of the security agencies in the country, provide basic amenities and infrastructures i.e. street lights and ensure a conducive environment for working with all its appropriate pecks.

The study concluded that residents were skeptical about police protection and crime in the area was endemic in nature, however, its intensity decreased as one moves outward from the center of the market

\section{REFERENCES}

1. Adelakun, E (1990) Crime as Social Adjustment to Structural Adjustment Programme. Paper presented at a Seminar for Crime and Crime Control in Nigeria, University of Jos. November 26.

2. Adigun F.O (2012). Spatio-temporal Analysis of Urban Crime in Selected Nigerian Cities, Unpublished Ph.D. Dissertation Department of Urban and Regional Planning LAUTECH Ogbomoso.

3. Adelamo (1979): A Survey of the Factors Affecting Market Patronage on the Path to Regional Development of Okipupa Nigeria.

4. Agbola, T. (1997): Crime Mapping in Nigeria using GIS. Journal of Geographic Information System, vol. 6 No. 5, October 6, 1997.

5. Agboola T. (2004): Reading in Urban and Regional Planning cited from Challenges of Urbanization and Urban Growth In Nigeria. American Journal of Sustainable cities and society.

6. Ahmed, Y.A. (2010): 'Trend and Pattern of Urban Crime in Southwestern Nigeria, Unpublished Ph.D Dissertation, University of Ilorin, Nigeria.

7. Ajibade, D; Olopade. O.A and Erinosho, T.O (2011) "Children Exploitation in the Apprenticeship Process: Empirical Exposition from Abeokuta” International Journal of Social Sciences (in press).

8. Akinrinde, S (2007) Menace of Bandits, Newswatch Magazine, April 22, Lagos: Newswatch Communications Ltd.

9. Alemika, E.E.O (1999): 'Police-Community Relations in Nigeria: What went wrong?'Law Enforcement Review, January-June, pp 21-27.

10. Arinze, P.E (2010) An Evaluation of the Effect of Armed Robbery on Nigeria Economy, Transcampus Journal of Research in National Development, vol.8 no.2.Dec.

11. Ayodele, J. O. (2015) Crime Reporting Practices Among Market Women in Oyo, Nigeria. Sage Journals. http://www.uk.sagepub.com/aboutus/openaccess.htm

12. Balogun, F.A (1998) Critical Appraisal of Retail Commercial Land Use, Sango Market as a Case Study. Unpublished thesis, Town Planning Department, The Polytechnic, Ibadan. P2.

13. Bressler, Raymond G. Jr and Richard A. King (1970) Markets, Prices, and Interregional Trade, New York:John Wiley and Sons

14. Cromie, (1993, Fisher 1991): Crimes against Business: A review of Victimization, Predictors and Prevention. No.11

15. Dambazu, A.B (1994) Law and Criminality in Nigeria, Ibadan: University Press, Chapter 6, pg 143-146.

16. Egwu, S (1990) State, Crime, and Ideology in Nigeria, Ibadan: University Press, Chapter 6,pg 143-156

17. Filani, M.O and Richard P.R, 1976. Period Market Systems and Rural Development. Ibarapa as a Case Study, Nigeria. Savanna. 3: 149-162.

18. Fisher, B \& Looye, J.W (2000). Crime and Small Businesses in the Midwest: An examination of Overlooked Issues in the United States. Security Journal, 13(2), 45-72.

19. Fisher, B (1991). A Neighborhood Business Area is Hurting: Crime, Fear of Crime and Disorders take their toll. Crime \& Delinquency, 37, 363-373.

20. Hale, C.D (2004) Police Patrol Operation and Management USA: Pearson Education Inc.

21. Ige, J.O. (2015) Spatial Analysis of Crime in Oke-Ogun Area of Oyo State, Nigeria. A PhD Thesis submitted to the Department of Geography, Obafemi Awolowo University, Ile-Ife, Osun state, Nigeria

22. Kornblum, W and Julian, J (2004) Social Problems, London: Pearson Prentice Hall. 
23. Mitchell H. E. (2002) quoted in "Marketing Management" Sontakki C. N. , Kalyani Publishers, New Delhi $\mathrm{p} 1$

24. Newman, O. (1972): "Defensible Space: People and Design in the Violent City," London: Architectural Press, Pp. 2.

25. Nwafor, J.C, 1982. Marketing System and Periodic Market, Nigeria. In: Maps. Pp: 114.

26. Odekunle, F. (2005): 'Crime and Social Deviance' in Akeredolu, Social Development in Nigeria; Ibadan: University Press Ltd, pg 68.

27. Okafor (2011): Youth Unemployment and Implication for Stability of Democracy in Nigeria: A nexus and Implication for National Development.

28. Okunola (2002): "Prison as Social System" cited in Sociology: Current and Perspectives. Edited by Uche C.A and Austin N.I.

29. Onoge, O.O (1988): Crime and Control in Nigeria: The problem of Robbery in Ukwu. Dimensions of Social Problems in Nigeria.Kuru:NIPSS.

30. Oyebanji, J.O (1982): Economic Development and the Geographical of Crime: An Empirical Analysis. Vol. 6, Issue 5, pp 453-458 September, 1982.

31. Schaefer, R.T (1989): 'Sociology' Third Edition Western Illinois University in Collaboration with Robert P. Lamm McGraw, Hill, Inc.

32. Taminu, B. (2006): Convicts Views of the Criminal Justice System in Nigeria in the National Question and Some Selected Topical Issues on Nigeria. Pp. 294-309.

33. Vagale, L.R 1973. Anatomy of Traditional Markets in Nigeria: Focus on Ibadan city. The Polytechnic, Ibadan, Town Planning Development 